Jacek TOMCZYK

IEiB UKSW Warszawa

Grzegorz BUGAJAK

IF UKSW Warszawa

\title{
Wokół ewolucji i kreacji - wstępna analiza ankiet nauczycieli i studentów
}

Ludzie będąc częścią świata ożywionego, zawsze żyli w przekonaniu o swej wyjątkowości. Przyjmowana do XIX wieku teoria stałości i niezmienności gatunków stawiała człowieka „na szczycie” świata ożywionego. Przyrodnicza wizja stałości gatunków doskonale korespondowała z biblijnym obrazem stworzenia swiata - wszak Księga Rodzaju ukazuje ludzi jako istoty wyjątkowe, bo stworzone na obraz i podobieństwo samego Boga. W drugiej połowie XIX wieku została ogłoszona przez Karola Darwina teoria ewolucji. Warto podkreślić, że Darwin publikował swoje dzieło z mieszanymi odczuciami. W liście do Charlesa Lyell’a pisał: Patrze na Pana jak na lorda nauk przyrodniczych, toteż prosze, aby Pan po przeczytaniu całości, przejrzał jeszcze raz tytuły tej części ostatniego rozdziału, w której dokonuję rekapitulacji. Z niepokojem oczekuje pańskiej oceny co do równowagi argumentów za i przeciw w mojej ksiązce $e^{1}$. Wątpliwości Darwina wynikały ze świadomości zburzenia dotychczasowej wizji człowieka. W świetle bowiem „nowej teorii” człowiek stanowil jedynie biologiczny gatunek, który podlegał tym samym, co inne organizmy, prawom biologicznym. Obawy wywołania konfliktu były całkowicie uzasadnione. Sadzić jednak należy, że Darwin w najśmielszych wyobrażeniach nie przypuszczał, że teoria ewolucji będzie przysłowiową „kością niezgody" przez następne zgoła sto pięćdziesiąt lat. Wciąż raz po raz, tak wśród przyrodników, jak teologów i filozofów, odżywają debaty, dotyczące zagadnień ewolucyjnych ${ }^{2}$. Często dyskusje te rzucają nowe światło na stare problemy - to bez wątpienia zachęca do ich kontynuowania. Niemniej jednak pojawiają się i takie debaty, które osadzone na niewłaściwym zdefiniowaniu pojęć nie tylko, że nie przynoszą żadnych rozwiązań, ale wprowadzają wiele chaosu.

1 White M., Gribbin J., Darwin. Żywot uczonego, Prószyński i S-ka, Warszawa 1998, 210.

2 Rennie J., 15 odpowiedzi na nonsensowne tezy kreacjonistów, Świat Nauki 9(2002)66-73; Krawczyk J., Człowiek nie zaistniał przez przypadek. Przegraleś Darwinie!, Sandomierz 2003; Tомсzук J., O rozdzielności plaszczyzn, Na Początku 7/8(2005), 246-260; JoDKowski K., Eskapizm teologii i filozofii katolickiej w sprawie „nauka a religia”, Na Początku 7/8(2005)261-290. 


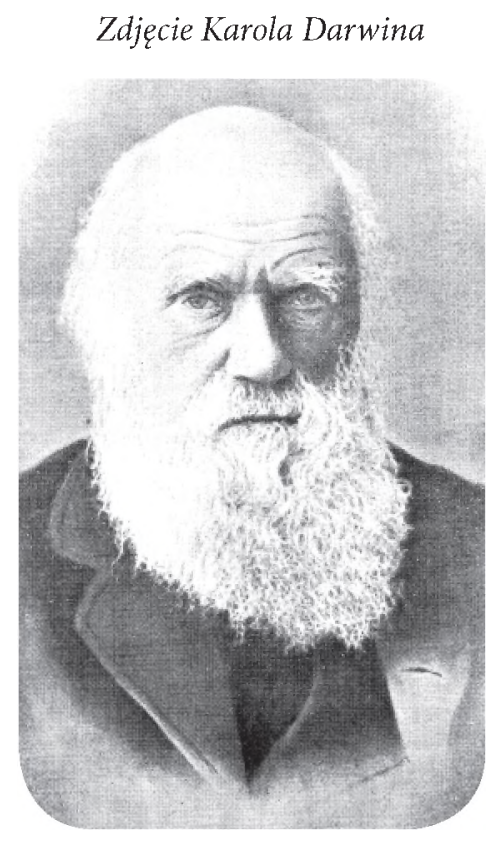

Prowadzone dysputy zainicjowały podjęcie, w ramach międzynarodowego programu Global Perspectives on Science and Spirituality (GPSS) ${ }^{3}$, tematu badawczego Current controversies about human origins. Between anthropology and the Bible. Projekt został skoncentrowany wokół rzekomego konfliktu pomiędzy naukami przyrodniczymi i filozoficzno - teologicznymi w odniesieniu do problemu pochodzenia czlowieka. Celem badań była próba poznania czy wspomniany konflikt realnie istnieje. Nie można bowiem wykluczyć faktu, że kontrowersje między ewolucją i kreacją nie mają merytorycznego uzasadnienia, a są jedynie sztucznie napędzane między innymi przez amerykańską literaturę popularnonaukową. Jeżeli jednak konflikt pomiędzy naukami przyrodniczymi i humanistycznymi w odniesieniu do powstania człowieka współczesnego realnie istnieje warto poznać jego źródla - co powinno przyczynić się do uporządkowania, zbyt emocjonalnej czasami, dyskusji nad tym zagadnieniem.

Jednym ze sposobów realizacji zamierzonego celu były badania ankietowe, przeprowadzone wśród studentów, nauczycieli oraz samodzielnych pracowników naukowych. Wspomniane grupy respondentów reprezentowały trzy dziedziny naukowe: teologię, nauki przyrodnicze oraz filozofię. W niniejszej pracy zostaną zaprezentowane wybrane wyniki ankiety skierowanej do grona nauczycieli. Odpowiedzi studentów potraktowano natomiast wybiórczo, aby mocniej wyakcentować poglądy nauczycieli.

Program badawczy zorganizowany został przez Interdisciplinary University of Paris oraz Fundację Tempeltona. Projekt prowadzony był w ramach Instytutu Filozofii oraz Ekologii i Bioetyki UKSW w Warszawie (ID10014). 


\section{Material}

Nauczyciele katechezy i nauk przyrodniczych (biologii, chemii, fizyki), jak również studenci teologii, filozofii i nauk przyrodniczych (biologii i ochrony środowiska) zostali poproszeni o wypełnienie ankiety, zawierającej 11 pytań. Dotyczyly one takich zagadnień jak: istnienie konfliktu między ewolucjonizmem i kreacjonizmem; definicja kreacji i ewolucji; istnienie pierwiastka duchowego w człowieku; sposób odczytywania Pisma św., a w szczególności pierwszych stron Księgi Rodzaju. Z około 1000 rozprowadzonych ankiet zwrócono 449, co można uznać za wynik satysfakcjonujący, mając na uwadze fakt, że badania takie zostały przeprowadzone w Polsce po raz pierwszy.

Ankiety objęly nauczycieli z dwóch rejonów Polski: obszaru górnego Śląska (tereny Gliwic, Tarnowskich Gór, Bytomia, Zabrza, Lublińca) oraz obszaru łódzkiego (Łódź, Piotrków Trybunalski, Łask). Badana reprezentacja nauczycieli została podzielona na 3 grupy wiekowe: a) 26-35 lat -nauczyciele o niewielkim stażu, a tym samym reprezentujący stosunkowo młode pokolenie, urodzone w latach 70., co należy identyfikować ze schyłkiem epoki PRL-u. b) 36-45 lat - nauczyciele o średnim stażu zawodowym, wychowani w latach 60.; c) powyżej 45 roku życia - nauczyciele o dużym stażu zawodowym, grupa wychowana w okresie „głębokiego komunizmu”. Wszystkie kategorie wiekowe nauczycieli są reprezentowane przez podobną ilość respondentów.

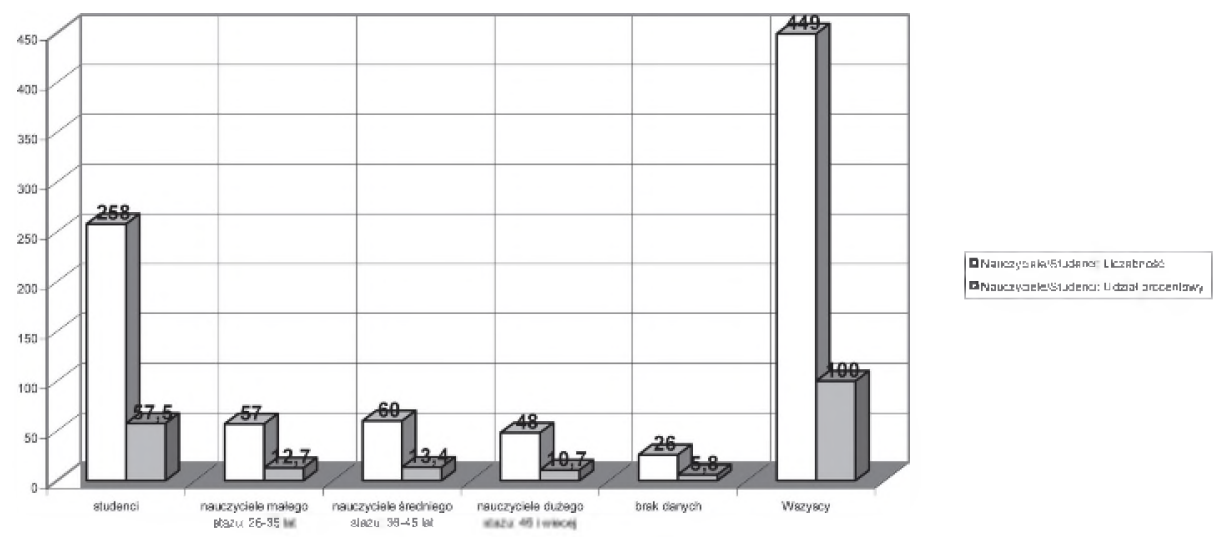

Ankiety zostały skierowane do nauczycieli katechetów oraz przyrodników. W trakcie analizy ankiet okazało się jednak, że zakres nauczanych przedmiotów jest nieco szerszy niż początkowo zakładano. Skłoniło to do pogrupowania nauczycieli wedle następującego wzorca: a) nauczyciele uczący wyłącznie katechezy; b) nauczyciele uczący wyłącznie biologii bądź przyrody; c) nauczyciele uczący katechezy oraz innego przedmiotu np. wychowania do życia w rodzinie; oraz d) nauczyciele innych przedmiotów biorący udział w badaniu ankietowym. 


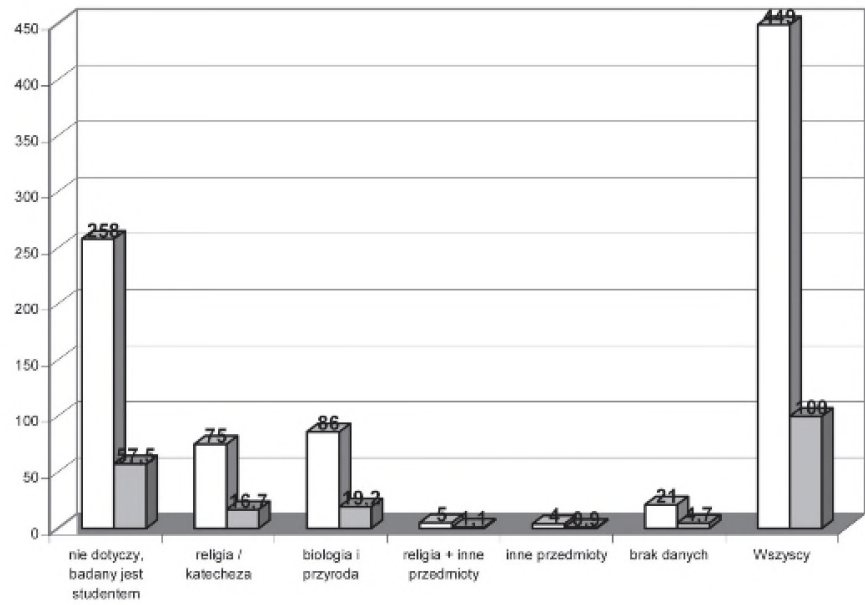

DHauczany przedmiot: Liczebnoḱ QNauczany przedmiot: Udziä procentow

Kolejnym istotnym elementem analizy okazało się pogrupowanie nauczycieli pod względem miejsca ich pracy. Szeroki zakres szkół podyktował konieczność pogrupowania ankietowanych nauczycieli na następujące kategorie: a) nauczycieli pracujących bądź w szkołach podstawowych bądź gimnazjach, lub pracujących w obu tych typach szkół równocześnie - są to zatem pedagodzy pracujących z dziećmi młodszymi; b) nauczycieli pracujących wyłącznie w szkołach ponadpodstawowych bądź ponadpodstawowych i gimnazjalnych równocześnie - grupa ta pracuje ze starszymi dziećmi i młodzieżą; c) nauczycieli nie podających miejsca zatrudnienia, bądź emerytowanych pracowników szkolnictwa.

Obok nauczycieli ankietami zostali objęci również studenci Uniwersytetu Śląskiego, Akademii im. Jana Długosza w Częstochowie, Uniwersytetu Kardynała Stefana Wyszyńskiego w Warszawie oraz Wyższego Seminarium Duchownego w Łodzi. Zostali oni podzieleni wedle kierunków studiów: a) filozofii; b) biologii lub ochrony środowiska; c) teologii oraz prawa kanonicznego; d) nie podający kierunku swych studiów. Poszczególne grupy pod względem liczby respondentów są porównywalne.

W badanej grupie, zarówno nauczycieli, jak i studentów, pozytywny stosunek do religii zadeklarowało ponad $95 \%$ respondentów. W prezentowanej ankiecie pominięto natomiast szczegółową kwestię religijnej przynależności wspólnotowej. Jakkolwiek warto zaznaczyć, że w ankietowanej grupie jedynie $48 \%$ zadeklarowało przynależność do kościoła rzymsko-katolickiego, 52\% natomiast nie uściśliło swej tożsamości religijnej. 


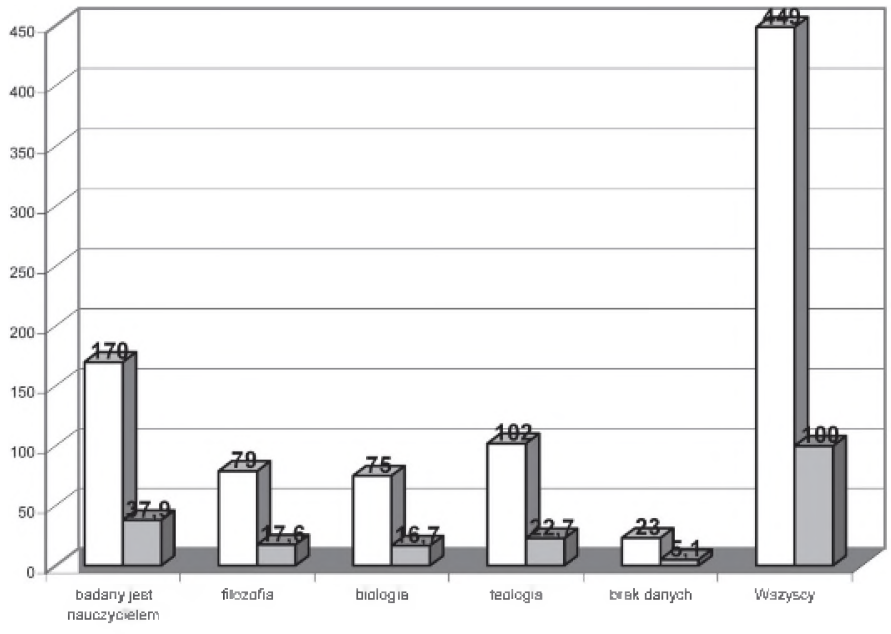

\section{Wyniki ankikety}

1. Kluczowe pytanie ankiety dotyczyło postrzegania ewentualnego konfliktu między kreacjonizmem, a ewolucjonizmem. Kwestia ta w zasadzie sprowadza się do pytania o priorytet poznania teologicznego i przyrodniczego w kwestii pochodzenia człowieka. Konflikt ten w zdecydowanej większości dostrzegają osoby niewierzące (55\%). Wśród osób wierzących przekonanie o wzajemnym wykluczaniu i konflikcie żywi niespełna 30\% ankietowanych. Osoby identyfikujące się z wyznawaną religią w zdecydowanej większości widzą spójność i wzajemne uzupełnianie poglądów nauk teologicznych i przyrodniczych. Taką spójność wśród osób niewierzących dostrzega zaledwie 5\% respondentów.

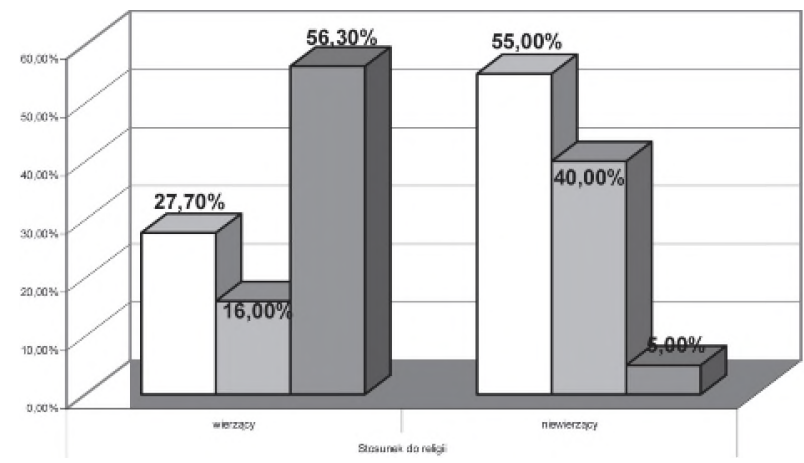

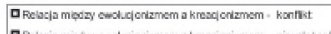

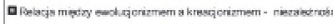

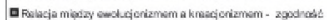


Zestawienie to wyraźnie wskazuje na istotną zależność między stosunkiem do religii, a oceną relacji ewolucja - kreacja. Dane te można interpretować tak, iż osoby niewierzące $-\mathrm{z}$ racji braku zainteresowania sprawami religijnymi - nie mając dostatecznej wiedzy z zakresu nauczania Kościoła widzą swoistą nieudolność nauk teologicznych odnośnie kwestii powstania człowieka. Często osoby takie traktują np. naukę Kościoła o grzechu pierworodnym w kategoriach historycznego wydarzenia, zaś pogląd taki, w świetle dzisiejszej wiedzy paleoantropologicznej, uważać należy za zdezaktualizowany. Tymczasem pomijają najistotniejszą kwestię, a mianowicie, że istotą nauki o grzechu pierworodnym nie jest sposób jego zaistnienia i przekazywania - kwestia ta pozostanie zawsze misterium iniquitatis - lecz nieposłuszeństwo i związana $z$ tym potrzeba Odkupienia ${ }^{4}$. Konflikt między ewolucją a kreacją $w$ tym ujęciu wynikałby $\mathrm{z}$ braku należytej wiedzy z zakresu teologii i filozofii.

Nie można też wykluczyć innego wyjaśnienia omawianej zależności, a mianowicie iż osoby wierzące, widzące harmonię i spójność poglądów teologicznych i przyrodniczych, opierają się na błędnej definicji ewolucji lub kreacji. Kwestia ta zostanie poruszona w dalszej części artykułu.

2. Ciekawym zestawieniem okazała się zależność między nauczanym przedmiotem, a oceną relacji ewolucja - kreacja. Jak można było przypuścić grupą nauczycieli, która w największym stopniu dostrzega sprzeczność między ewolucjonizmem a kreacjonizmem, będą nauczający przedmiotów przyrodniczych - intuicja ta znajduje swoje potwierdzenie, jako że prawie $22 \%$ nauczycieli tych przedmiotów dostrzega wyraźny konflikt, a 17\% nie widzi powiązania między tymi zagadnieniami. Zaskakującym jest natomiast, że równie dużo, bo aż $16 \%$ katechetów i $20 \%$ uczących religii z innym przedmiotem, również dostrzega konflikt.
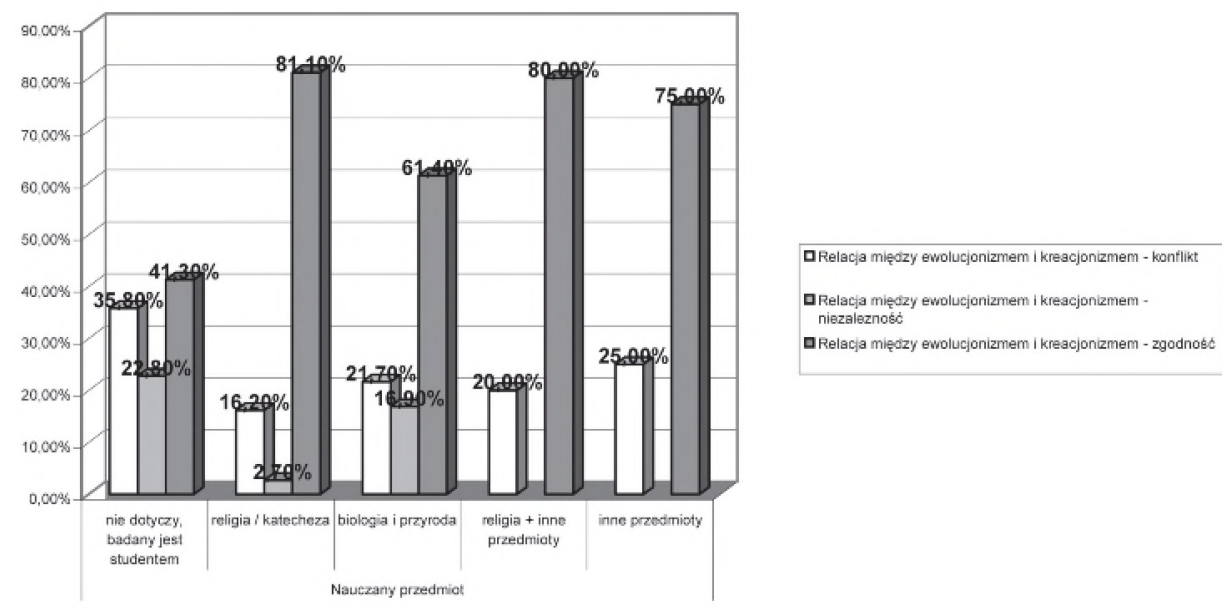

4 Pietras H. (red.), Grzech pierworodny. Augustyn. Dzieje procesu Pelagiusza, WAM, Kraków 1999. 
Grupa widząca konflikt między ewolucją a kreacją, jakkolwiek w porównaniu z osobami dostrzegającymi spójność tych poglądów lub brak konfliktu jest niewielka, jednak obejmuje jedną piątą respondentów. Być może przyczyn tego należy dopatrywać się w braku należytej wiedzy bądź z zakresu nauk przyrodniczych bądź teologicznych. Wiedza ta nierzadko czerpana jest przez nauczycieli nie $z$ fachowej literatury przedmiotu, lecz jedynie z czasopism o charakterze popularnonaukowym i publicystycznym. Te natomiast nie rzadko prezentują błędne poglądy odnośnie wspomnianej problematyki. Przykładem może być artykuł Ewy Polak-Pałkiewicz Ewolucja - obłok wiedzy czy ideologi $i^{5}$. Autorka tekstu, mimo iż przyznaje się do przyrodniczego wykształcenia, afirmuje tezę, iż teoria Darwina - w domyśle teoria ewolucji - nie jest naukowa, jako że nie posiada wystarczających dowodów. Wiadomo natomiast, że jednym z kryteriów wiedzy naukowej jest jej wysoki stopień sprawdzalności. Innymi słowy, prawdziwość teorii naukowych rozpoznaje się poprzez zestawienie ich przewidywań z odkrywanymi faktami. Głoszony zarzut, iż teoria ewolucji nie dostarcza należytych dowodów, a zatem nie spełnia warunku testowalności, w rzeczywistości nie dotyka stworzonej przez Karola Darwina teorii. Opisuje ona bowiem nie przebieg zdarzeń ewolucyjnych, lecz jedynie ich mechanizmy. Niezdolność przewidzenia przyszłości jest problemem zagadnień filogenetycznych, a zatem całkowicie innej klasy teorii. Teorię ewolucji łatwo byłoby obalić, na takiej samej zasadzie, jak inne teorie nauk doświadczalnych. Wystarczy sprawdzić, jakie są rzeczywiste skutki zastosowania doboru w stosunku do zmiennych cech organizmów - czynią to od stuleci choćby hodowcy. Teoria ewolucji Darwina poddaje się więc doświadczalnemu testowaniu i jest teorią naukową nie różniąca się metodologicznie od typowych teorii fizyki czy chemii. Przybiera ona dziś postać twierdzenia, że jeśli dobór działa na populację samopowielających się osobników o cechach ściśle dziedziczonych, ale losowo się zmieniajacych, to w kolejnych pokoleniach rozkład zmienności tych cech w populacji przekształca się w kierunku odpowiednim do dzialania doboru. Teoria ta objaśnia więc ewolucję, jako skutek selekcji osobników populacji przez środowisko na podstawie ich zdolności do przekazania swoich cech następnemu pokoleniu ${ }^{6}$. Dziwić się więc należy Autorce artykułu, która kontestuje twierdzenie, że teoria ewolucji jest teorią naukową.

Być może takie i podobne publikacje stoją u podstaw braku należytej wiedzy z zakresu ewolucji - kreacji, co wpływa na poglądy respondentów dostrzegalne w wynikach przeprowadzonej ankiety.

5 Polak-Pa£kiewicz E., Ewolucja - oblok wiedzy czy ideologii, „Niedziela”46(2006)26; Tомсzүк J., Czy spory wokót ewolucji sq uzasadnione? "Niedziela"49(2006) 28.

6 Dzik J., Sposoby odczytywania kopalnego zapisu ewolucji, w: Bugajak G., Tomczyк J. (red.), Wspótczesne kontrowersje wokót początków człowieka, Wyd. Św. Jacka, Katowice 2007 (w druku). 
Warto również podkreślić, że nauczyciele przedmiotów teologicznych w mniejszym stopniu dostrzegają konflikt, niż katecheci uczący również innych przedmiotów (np. wychowania do życia w rodzinie). Zależność tę w jakimś stopniu wyjaśnia fakt reorganizacji szkolnictwa po 1991 roku. Radykalne zmiany programowe podyktowane między innymi niżem demograficznym wymogły na nauczycielach, w tym przedmiotów przyrodniczych (np. biologii, fizyki), uzyskanie dodatkowych kwalifikacji, które umożliwiłyby im nauczanie również innych przedmiotów. Oznacza to zatem, że około $20 \%$ katechetów początkowo w swym stażu zawodowym prowadziło zajęcia z całkowicie odmiennych przedmiotów niż katecheza. To być może wyjaśnia fakt ich bardziej krytycznego nastawienia do oceny relacji między ewolucjonizmem a kreacjonizmem, niż nauczycieli o wyłącznie katechetycznym przygotowaniu.

Podobna co wyżej zależność została przeanalizowana odnośnie do studentów. Największa grupa respondentów, dostrzegających wyraźny konflikt, wywodzi się ze studiujących nauki biologiczne.

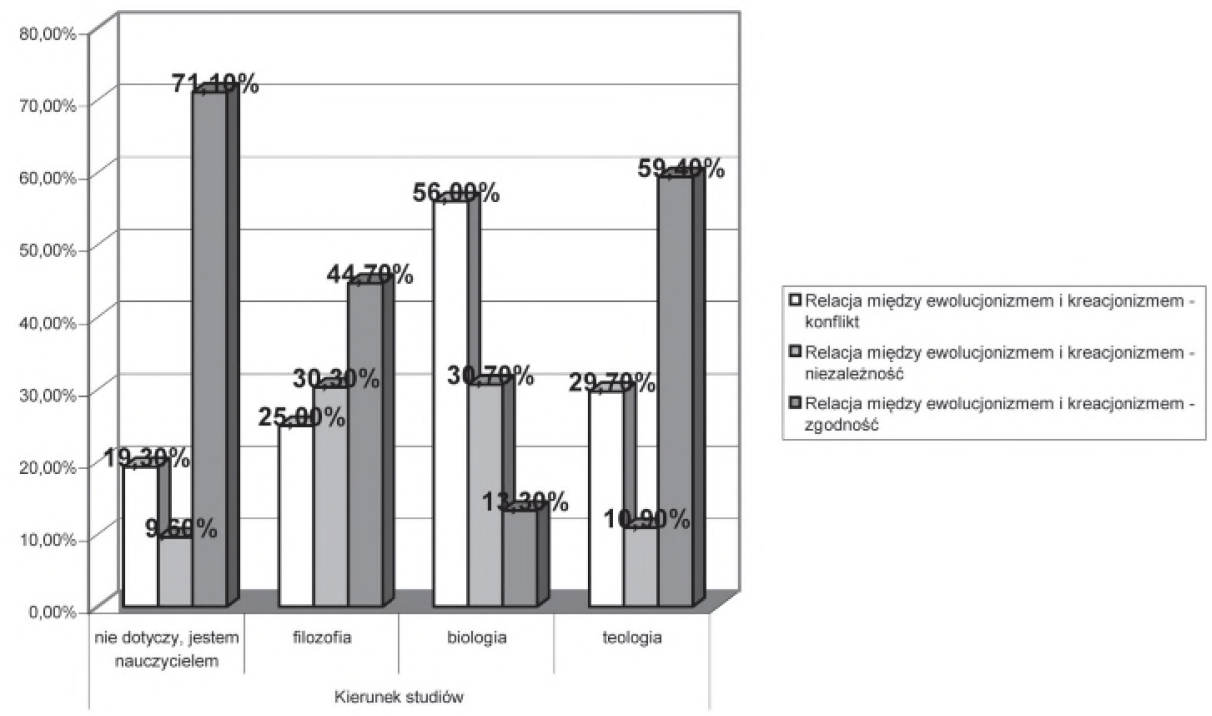

Może to wynikać ze swoistego sposobu nauczania biologii na uczelniach, lub słabego wykształcenia religijnego. Młodzież studiująca przeszła kurs katechezy w zakresie szkoły, co być może wskazuje na nieodpowiednie prowadzenie zajęć $\mathrm{z}$ tego przedmiotu. Nie można jednak wykluczyć faktu, iż przekonanie o konflikcie zostaje przekazane w trakcie zajęć uniwersyteckich. Raz po raz odżywa bowiem w środowiskach akademickich pogląd, iż Darwin w swym dziele polemizował $\mathrm{z}$,przekonaniami teologicznymi”. Tymczasem zamiarem Darwina nie było kontestowanie idei kreacji, lecz przyrodniczej koncepcji niezmienności gatunków. Jakkolwiek problemy dotyczące celowości powstania świata były te- 
matem nurtującym Darwina, jednak pisząc swe dzieło nie czynił tego z pobudek ideologicznych - by obalić nauczanie Kościoła, lecz przyrodniczych - chcąc wykazać błędność teorii stałości i niezmienności gatunków ${ }^{7}$. Darwin zapytany przez Duke of Argylla, czy jest absolutnie przekonany, ze piękno natury jest wyłącznie dziełem przypadku, odpowiedział: takie przekonanie z przytłaczajaca siła czesto do mnie przychodzi, jednak kiedy indziej wydaje się, że odchodzi ode mnie $e^{8}$. Swoista postawa wahania Darwina utwierdza tylko w przekonaniu, ze O powstaniu gatunków było z założenia dziełem przyrodniczym, a nie traktatem filozoficzno-teologicznym o celowości i kreacji. Takim zaś uczynili go „ideologizujący” interpretatorzy między innymi Ernst Haeckel, który ideę teorii ewolucji traktował jako naukę wymyśloną wyłącznie po to, aby pogrzebać chrześcijaństwo i Kościót'.

Równie ciekawym jest fakt, że także wśród studentów teologii i filozofii odpowiednio $25 \%$ i $30 \%$ - a zatem stosunkowo duża grupa - również dostrzega konflikt. Trudno jednoznacznie orzec z jakich powodów aż jedna czwarta respondentów zauważa wyraźny brak zgodności między biologiczną nauką o powstaniu człowieka z teologiczną doktryną kreacyjną. Być może wytłumaczeniem jest fakt, że studiujący nauki humanistyczne poszukując odpowiedzi na pytanie o istotę człowieka, jego duchowość i wartości, uzyskują je na kanwie płaszczyzny nauk filozoficzno-teologicznych. Pozyskana wiedza jest jednak często nieweryfikowalna empirycznie, co w oczach młodego pokolenia identyfikowane jest z jej słabością i nieudolnością ${ }^{10}$. Wydaje się, iż z tego też powodu studiujących przedmioty humanistyczne, dostrzegają konflikt pomiędzy ewolucjonizmem - identyfikowanym z wiedzą pewną i sprawdzalną, a kreacjonizmem - wiedzą opartą w mniejszym lub większym stopniu na spekulacjach.

Ankiety wskazują, że konflikt między naukami teologicznymi i przyrodniczymi odnośnie początków człowieka zarówno wśród nauczycieli jak i studentów, wprawdzie nie jest bardzo rozpowszechniony, jednak obejmuje nieomal jedną trzecią respondentów.

3. Pogrupowanie nauczycieli wedle wieku, a tym samym stażu zawodowego, miało na celu uchwycenia ewentualnej zależności między prezentowanymi poglądami, a okresem kształcenia. Można bowiem założyć, że nauczyciele dużego stażu zawodowego, wychowywani w „glębokim komunizmie” PRL-u, będą prezentować poglądy głoszące sprzeczność między ewolucją i kreacją.

Darwin K., Dzieta wybrane. Tom VIII: Autobiografia i Wybór Listów, PWRiL, Warszawa 1960, 42-49.

8 Bowler P.J., Charles Darwin The Man and His Influence, Cambridge University Press 1996, 207.

9 Haeckel E., Ueber unsere gegenwärtige Kenntnis vom Ursprung des Menschen. Verlang von E. Strauss, Bonn 1899.

10 Tomсzyк J., Antropologia filozoficzna i przyrodnicza w poszukiwaniu istoty człowieka, „Studia Philosophiae Christianae"1(2003)120-135. 
Materializm dialektyczny wraz $\mathrm{z}$ antyklerykalną propagandą przedstawiał chrześcijan, jako naiwnych prostych ludzi, bezkrytycznie przyjmujących słowa Księgi Rodzaju o mieszaniu gliny i lepieniu z niej pierwszego człowieka. Darwinizm był wykorzystywany do zwalczania wszelkich idei religijnych - w tym kreacjonizmu, który przedstawiano jako przebrzmiały światopogląd. Teoria ewolucji ukazywana była natomiast jako narzędzie wyjaśniające całościowy obraz świata. W jej świetle wyjątkowość człowieka pochodziła wyłącznie ze zmian ilościowych, które przechodziły skokowo w jakościowe ${ }^{11}$. Programowa laicyzacja obejmował zwłaszcza te osoby, które z racji wykonywanego zawodu miały możliwość kształtowania intelektualnego nowych pokoleń. Nic więc dziwnego, że największym naciskom byli poddawani przyszli nauczyciele czy klerycy.

Ankieta pokazała jednak, że osoby wychowane w PRL-u w mniejszym stopniu wykazują postawę krytyczną wobec zagadnień ewolucyjno-kreacyjnych, niż pokolenie najmłodszych nauczycieli. Prawdopodobnie wynika to $z$ sekularyzacji społeczeństwa i z dużej laicyzacji młodego pokolenia, które wykazuje coraz większe braki zarówno z zakresu teologii, jak i filozofii.

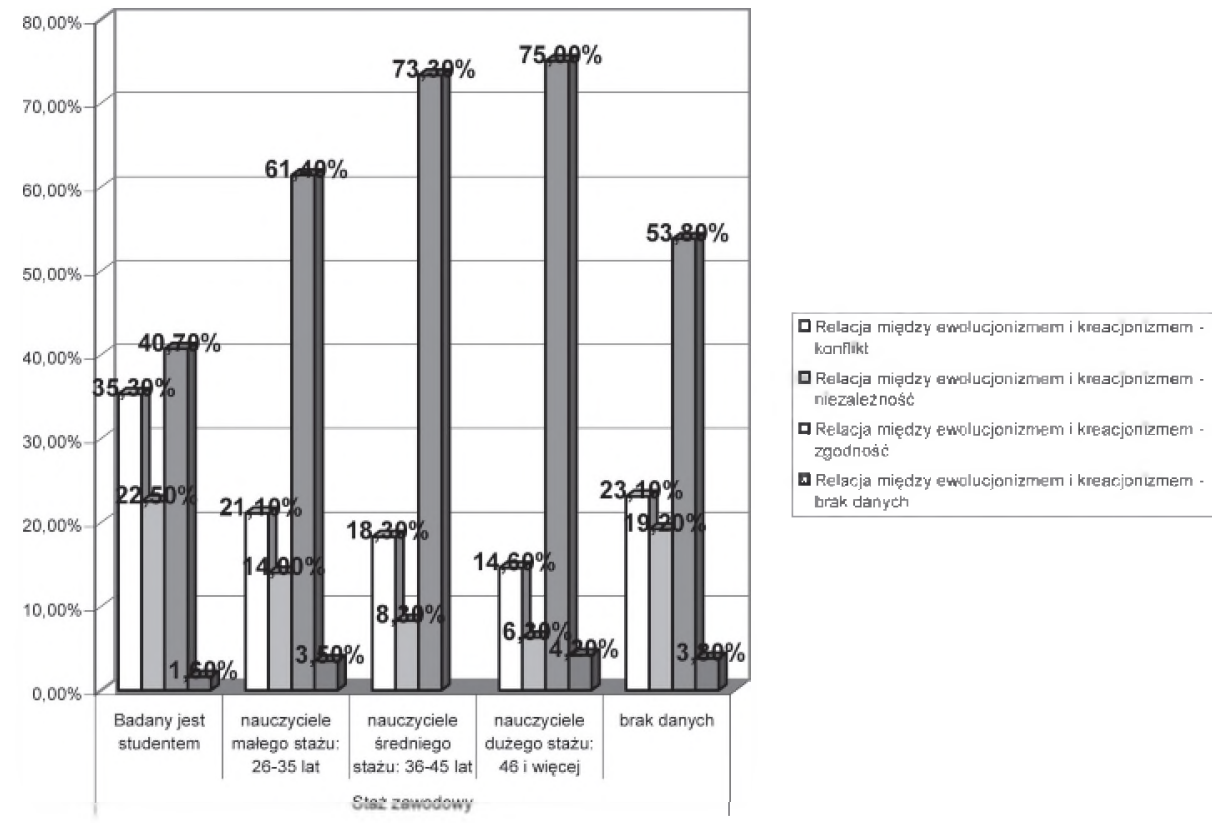

4. Skoro konflikt jest postrzegany przez znaczną liczbę nauczycieli i studentów warto podjąć poszukiwanie przyczyn takiego widzenia problemu. Dlatego w kolejnych pytaniach zwrócono uwagę na kwestię właściwego rozumienia

11 Petrusewicz K., Straszewicz A. (red.), Materialy do dziejów myśli ewolucyjnej w Polsce, PWN, Warszawa 1963; StęPIEŃ A.B., Wstęp do filozofii, TN KUL, Lublin 2001, 263-266. 
określenia „kreacja” i „teoria ewolucji”. Wydaje się bowiem, że jedną z przyczyn twierdzenia o sprzeczności jest błędne rozumienie znaczenia tych wyrażeń.

Ankietowani zostali postawieni przed zadaniem wyboru jednej z kilku podanych definicji kreacji. Pierwsza z nich - najbardziej teologicznie i filozoficznie poprawna - brzmiała: „istotą kreacji jest tworzenie z niczego oraz działanie, które wciąż trwa”. Definicja ta została wskazana przez zdecydowaną większość nauczających katechezy, choć warto zaznaczyć, że nauczyciele uczący katechezy oraz innego przedmiotu mieli więcej trudności z wyborem poprawnej odpowiedzi. Tym samym potwierdzają się wcześniejsze sugestie, iż nauczający początkowo w swym stażu zawodowym przedmiotów nie katechetycznych mają bardziej krytyczne nastawienie do oceny relacji między ewolucjonizmem a kreacjonizmem, niż nauczyciele o wyłącznie teologicznym przygotowaniu.

Jak widać z wykresu zaledwie jedna trzecia nauczycieli nauk przyrodniczych właściwie rozumie znaczenie 'kreacji' i wskazuje na poprawną jej definicję.

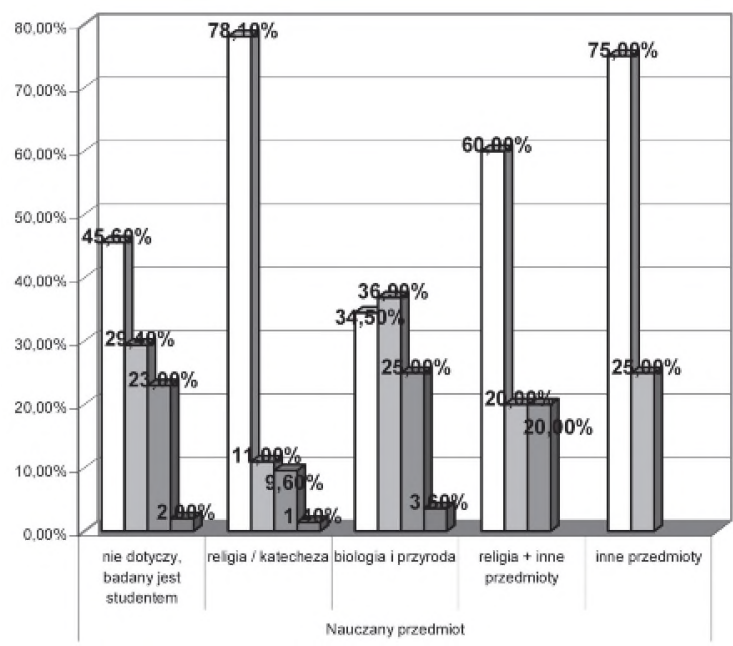

5. Analogicznie do pytania o wybór właściwej definicji kreacji, postanowiono również pytanie o właściwe rozumienie teorii ewolucji. Respondentom zostały przedstawione do wyboru cztery odpowiedzi na pytanie: jakie twierdzenie stanowi ważny element teorii ewolucji? Odpowiedź pierwsza brzmiała „rozwój organizmów zmierzający do określonego celu”, druga - wynikająca z teorii Lamarcka - „występowanie narządów jest zdeterminowane ich używaniem” ${ }^{2}$, trzecia (najbardziej poprawna) - „istnienie w świecie naturalnej zmienności i różnorodności”, i czwarta nawiązująca do biogenetycznego prawa E. Haeckla - „embrionalny rozwój osobniczy jest powtórzeniem etapów ewolucji” ${ }^{13}$.

12 LAMARcK J.B., Systeme analytique des connaissance positives d'homme, Paris 1830; GRĘBECKI A., Kinastowski W., KuźnICKI L., Ewolucjonizm, t. II, PWN, Warszawa 1962, 5-8.

13 Haeckel E., Generelle Morphologie, Berlin 1866. 
Wśród grona nauczycieli poprawną odpowiedź (trzecią) najczęściej wybierali uczący nauk przyrodniczych. Katecheci natomiast wybierając najczęściej określenie, iż „istotnym elementem teorii ewolucji jest rozwój organizmów zmierzający do określonego celu", wydaje się, że uzewnętrzniają swe teleologiczne tendencje interpretowania świata ożywionego. Tym samym można wyjaśnić, dlaczego zdecydowana większość z nich - 80\% nie widzi konfliktu między ewolucją a kreacją. Afirmacja celowościowej definicji ewolucji jest w ich przekonaniu spójna z teologiczną koncepcją Bożej Opaczności.
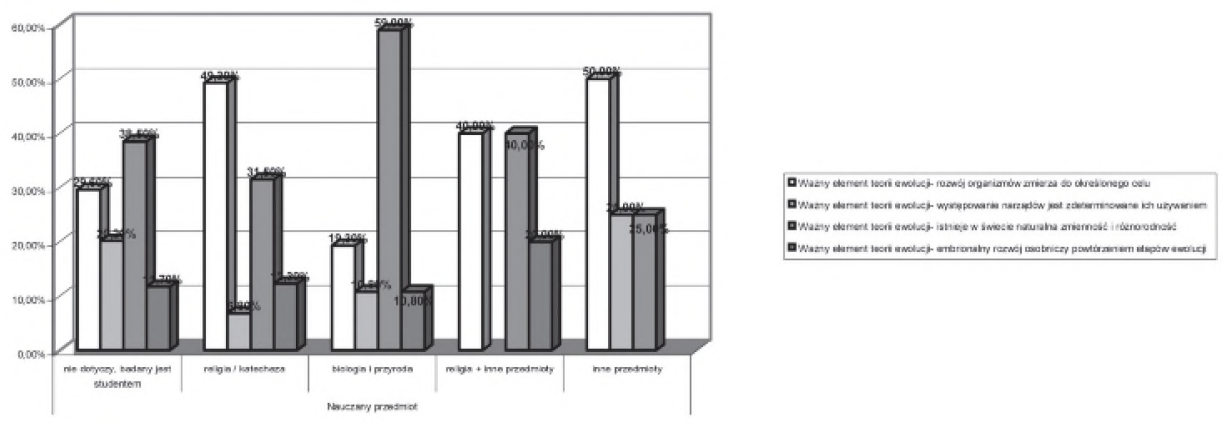

6. Wśród stawianych pytań znalazło się i takie, które porusza kwestię akceptowania w czlowieku pierwiastka duchowego. Nieomal wszyscy respondenci afirmują pogląd, że istotę ludzką znamionuje ten pierwiastek. Pojecie pierwiastka duchowego jest na tyle ogólne, że nie implikuje wiary w Boga.
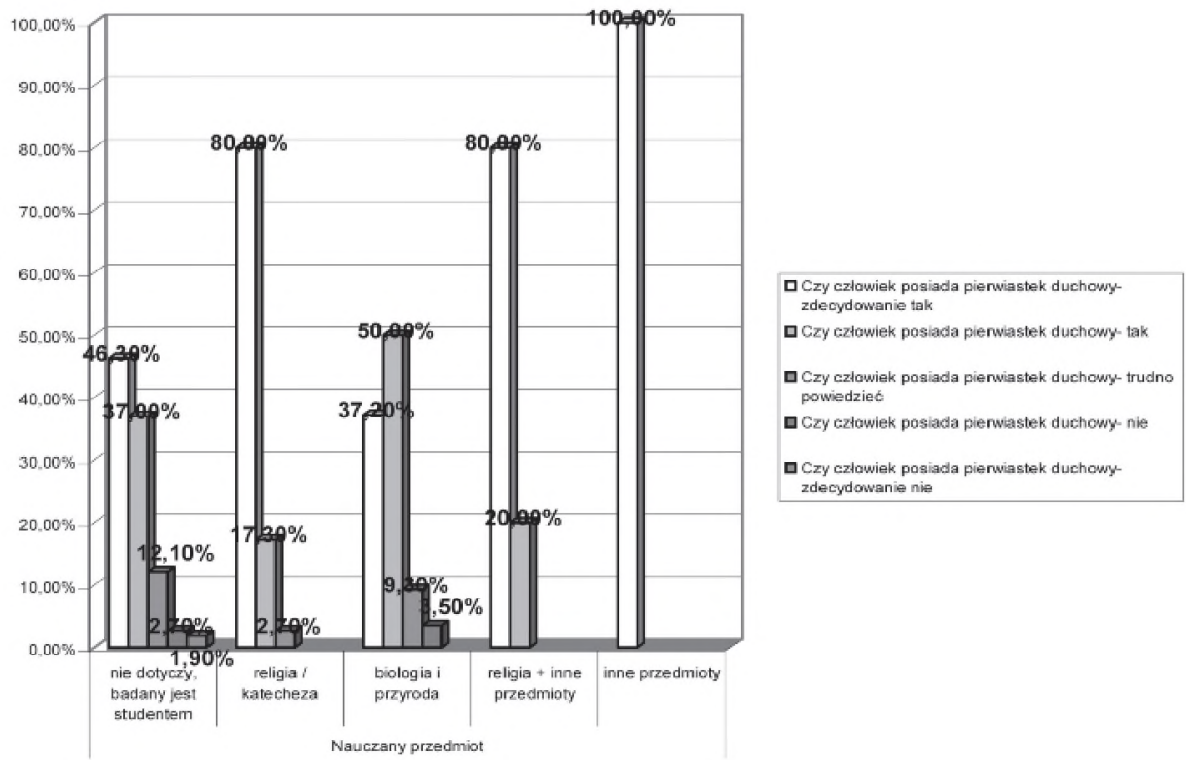
W niniejszej analizie pominięto kwestię pochodzenia tego pierwiastka. Warto niemniej wspomnieć, że najczęściej wskazywaną dziedziną, która dostarcza argumentów za istnieniem pierwiastka duchowego jest przez biologów uważana: psychologia w 40\%, religia w 50\% i genetyka w 6\%, zaś katecheci wskazywali na: religię w 90\%, psychologię 5\% i genetykę 3\%. Ciekawym jest, że uczący katechezy wraz z innymi przedmiotami aż w 20\% wskazali na genetykę i $80 \%$ na religię. Może to sugerować, że biolodzy znając, genetykę i widząc jej swoistą bezsilność w odpowiedzi na wiele istotnych pytań, poszukują wsparcia w innych dyscyplinach, np. w teologii. Natomiast dość powierzchowna wiedza z zakresu genetyki - stoi u podstaw swoistego 'zauroczenie' tą dyscypliną i czasem bezgranicznego zaufania do niej.

7. Poszukując przyczyn konfliktu nie sposób pominąć kwestii sposobu odczytywania Pisma świętego. Wiadomo bowiem, że istnieją osoby, zwłaszcza w niektórych środowiskach tzw. „kreacjonistów”, które odczytują Pismo święte w sposób literalny.

Na kanwie treści zawartych w Piśmie św. buduje się artykuły wiary. Te zaś są formułami orzekającymi, czy i w jakim stopniu jakaś prawda teologiczna zawarta jest w Objawieniu. Na tej podstawie można mówić o różnym stopniu kwalifikacji teologicznej określonego artykułu wiary. Stąd w teologii wymieniamy dogmaty: de fide divina cathololica definita (prawda, którą należy przyjąć wiarą boską i powszechną, i jest ona zdefiniowana w sposób uroczysty); de fide divina catholica (prawda nie zdefiniowana uroczyście, a jedynie wynika z powszechnego nauczania Kościoła); de fide divina (prawda wynikająca z objawienia prywatnego, w którą ma fakultatywny obowiązek wierzyć ten, któremu została objawiona); de fide ecclasiastica (prawda przyjęta ze względu na autorytet Kościoła); fidei proxima (prawda teologiczna będąca w stanie poznawania); theologice certa (prawda nie objawiona przez Boga - przynajmniej na tym etapie znajomości Objawienia - lecz uważana za prawdziwa przez większość teologów) ${ }^{14}$. Prawdziwość dogmatów wiary nie jest uzależniona od weryfikowalności zdań historycznych Pisma świętego lecz od Objawienia Bożego. Warto przypomnieć nauczanie Augustyna, który stwierdza, iz cokolwiek o naturze rzeczy w sposób pewny jest wykazane, nie jest przeciw Pismu Świętemu. Autorzy Biblijni nie chcieli bowiem uczyć o naturze rzeczy i tym, co w nich podpada pod zmysty, lecz tylko o tym, co prowadzi do zbawienia ${ }^{15}$. Stanowisko Kościoła odnośnie sposobu odczytywania i rozważania prawd zawartych w Piśmie Świętym zostało uszczegółowione podczas Soboru Trydenckiego (1545-1563) i było podyktowane tendencjami protestantyzmu. Jak wskazuje wielu historyków, spopularyzowanie tekstów biblijnych i odrzucenie

14 Stasiak S.J., ZawiŁa R., ABC teologii dogmatycznej, Oficyna Wydawnicza Signum, Wrocław 1993, 19-21.

15 Leon XIII, Enchiridion Biblicum. Documentum Ecclesiastica Sacrum Scripturam Spectantia, Neapol-Rzym 1954, 31-58. 
autorytetu Magisterium Kościoła na rzecz prywatnego osądu czytającego, propagowane przez protestantyzm, było reakcją na słaby poziom homiletyki nawiązujący często w Oświeceniu do mitologii ${ }^{16}$. Stąd w tekstach soborowych znajdujemy stanowisko wobec wspomnianych problemów. W dekrecie Soboru Trydenckiego odnajdujemy między innymi stwierdzenie: Ponadto dla powściagnięcia [niektórych] zuchwalych umystów oświadcza, by nikt, kto polega na własnej roztropności w rzeczy dotyczacej wiary i moralności, a wchodzacych w skład nauki chrześcijańskiej, i kto nagina Pismo św. do swoich pogladów - nie ośmielił się dawać objaśnień Pisma św. wbrew sensowi, który utrzymywała i utrzymuje święta Matka Kościól. Rzecza bowiem Kościola jest sądzić o prawdziwym sensie i tlumaczeniu Pisma świętego ${ }^{17}$. Również Sobór Watykański I podjął kwestię właściwego odczytywania Prawd Objawionych zawartych w Piśmie św., przypominając starą katolicką zasadę: veritas veritati contraria esse non potest (prawda nie może sprzeciwiać się prawdzie). Ojcowie soborowi uczynili to w następującym stwierdzeniu: Kościót nie tylko nie zwalcza rozwoju ludzkich nauk i umiejętności, ale wspiera je na różne sposoby oraz daży do ich rozwoju. Nie lekcewazy on ani nie gardzi korzyściami pochodzacymi z tych nauk i umiejętności dla zycia ludzi, ale przyznaje, że odpowiednio uprawiane, z pomoca Bożej laski prowadzq do Boga, skoro pochodzq od Niego, Pana umiejętności. Oczywiście Kościól nie sprzeciwia się, aby tego rodzaju dziedziny wiedzy posługiwały się własnymi zasadami i metodami we właściwym obszarze, ale uznając tę słuszna wolność zwraca uwage, aby sprzeciwiajac się Bożej nauce nie rodzily blędów, albo przekroczywszy własne granice, nie zajmowaly sie sprawami wiary i nie zniekształcaly ich ${ }^{18}$. Skoro źródłem prawdy tak naturalnej, jak i nadprzyrodzonej jest Bóg, zatem nie może być prawdziwej sprzeczności między nauką i wiarą.

Ankietowane grupy nauczycieli wskazały w przeważającej większości, że teksty Księgi Rodzaju ukazują symbolicznie fundamentalne prawdy o Bogu i człowieku. Respondenci są zatem świadomi, że biblijny opis stworzenia człowieka przedstawia ogromnie ważne prawdy w sposób antropomorficzny i byłoby naiwnością nie oddzielać zawartych w tym opisie prawd wiary od antropomorficznej formy, w jakiej zostały one przedstawione. Biblijny opis symbolicznie pokazuje z jednej strony, że człowiek został ukształtowany z ziemi, a zatem jest on częścią przyrody i jako taki został powołany do oddawania Bogu chwały w imieniu calej ziemi. Z drugiej natomiast, człowiek jest kimś więcej niż tylko częścią przyrody, bo przecież w "glinę jego ciała” sam Bóg tchnął ducha. Chodzi zatem o ontyczną szczególność człowieka w stosunku do zwierząt ${ }^{19}$.

16 Poradowski M., Kościól od wewnątrz zagrożony, Armel, Wrocław 1994, 15; PAPIESKa KomisJa Biblijna, Interpretacja Pisma Świętego w Kościele, Pallotinum, Poznań 1994.

17 GŁowa S., Bieda I. (red.), Breviarum Fidei, Księgarnia świętego Wojciecha, Poznań 1989, III, 14

18 GŁowa S., Bieda I. (red.), Breviarum Fidei, Księgarnia świętego Wojciecha, Poznań 1989, I, 64.

19 Sali J., Pochodzenie czlowieka w świetle wiary i nauki, w: BugaJAK G., TomczyK J. (red.), Wspótczesne kontrowersje wokót początków cztowieka, Wyd. Sw. Jacka, Katowice 2007 (w druku). 
Zaledwie 3\% nauczycieli biologii odczytuje teksty Genesis literalnie. Tym samym ewentualny konflikt między ewolucją, a kreacją nie może być w żaden sposób wyjaśniony dosłownym odczytywaniem Pisma św.
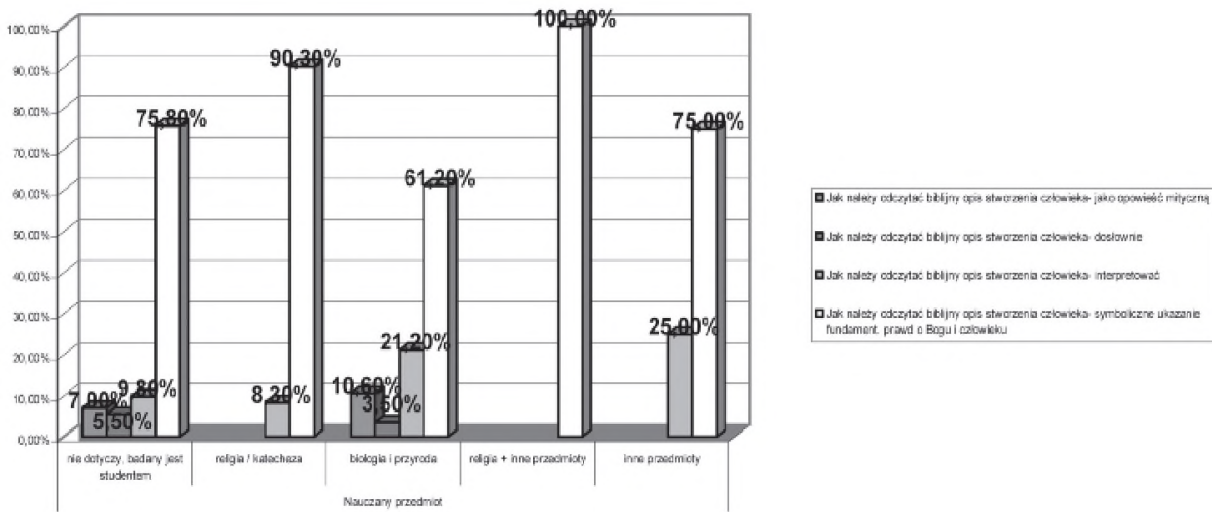

Również w grupie studentów zdecydowana większość ankietowanych traktuje biblijny opis w kategoriach symbolicznego ukazania prawdy o Bogu i człowieku. Warto zaznaczyć, że tej grupie podobnie jak wśród nauczycieli biologii pojawily się głosy traktujące Biblię, jako opowieść mityczną.

8. Interesującym zestawieniem jest pytanie dotyczące wyboru trafnej definicji kreacji z kwestią widzenia relacji ewolucja-kreacja. Wśród osób dostrzegających spójność poglądów teologiczno-przyrodniczych lub brak konfliktu dominuje poprawna definicja kreacji, jako tworzenie z niczego oraz działanie, które wciąż trwa. Natomiast w gronie respondentów deklarujących konflikt prócz wspomnia-

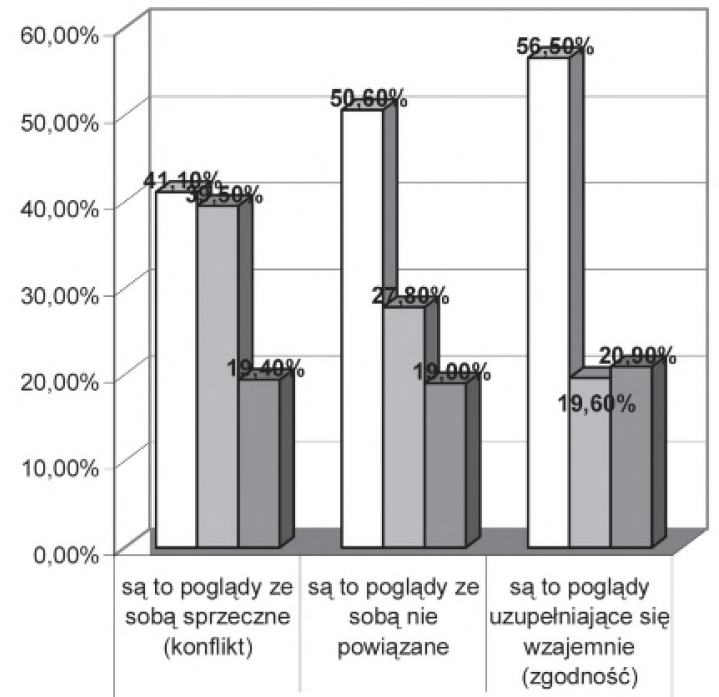

Relacja: ewolucjonizm-kreacjonizm $\square$ Istota kreacji to- tworzenie z niczego oraz dzialanie, które wciąż trwa

口Istota kreacji to- jednorazowy aktpowołnia bytów do istnienia z nicości

$\square$ Istota kreacji to- powtarzalny w odniesieniu do poszcz. bytów akt powołania 
nej definicji wyraźnie zaznacza się inna, a mianowicie: kreacja to jednorazowe powołanie bytów do istnienia z nicości. Być może w jakimś stopniu wyjaśnia to twierdzenie o sprzeczności, niemniej jednak nie jest to prawdopodobnie jedyne wyjaśnienie.

Podobnego zestawienia dokonano odnośnie do rozumienia ogólnych tez teorii ewolucji. Wśród widzących spójność poglądów ponad jedna trzecia respondentów przyjmuje określenie biologicznie poprawne - istotnym elementem teorii ewolucji jest fakt występowania w świecie naturalnej zmienności i różnorodności. Podobnie - jedna trzecia ankietowanych definiuje ewolucję celowościowo. Tym samym można to zinterpretować, iż dostrzeganie spójności jest rezultatem wyłącznie niewłaściwego traktowania, przynajmniej przez część respondentów samych pojęć.
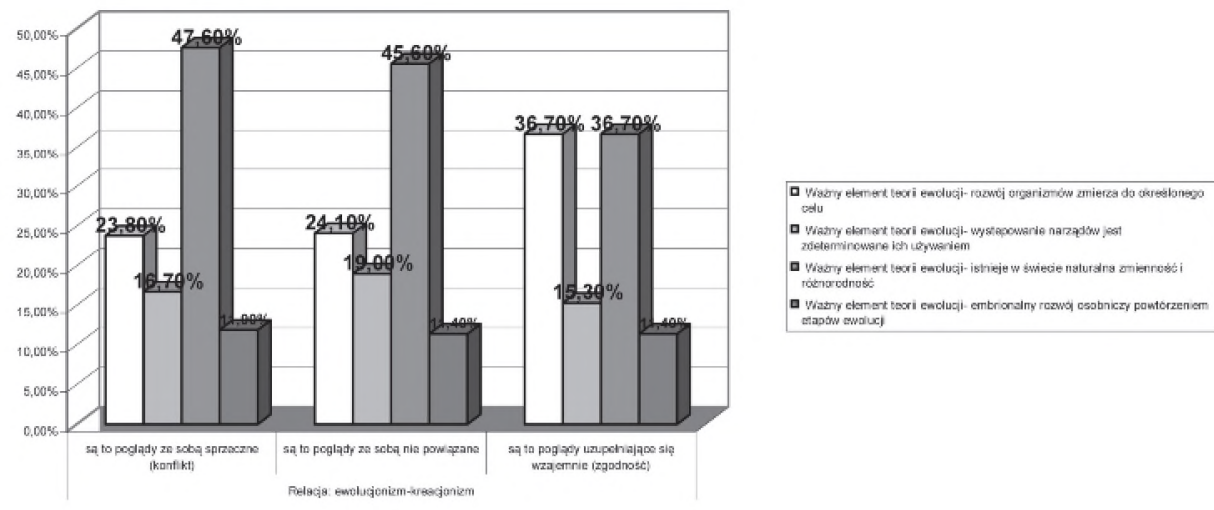

\section{Zakończenie}

Przez ostatnie sto pięćdziesiąt lat dyskusje między zwolennikami ewolucyjnego i kreacyjnego modelu powstania człowieka nacechowane były wzajemnymi oskarżeniami i podejrzeniami ${ }^{20}$. Teolodzy często czując zagrożenie ze strony przyrodniczej interpretacji prehistorii odrzucali teorię ewolucji, uważając ją za pogląd niezgodny z przekazem biblijnym i zasadą przyczynowości, a przez to uwłaczający zarówno Bogu jak i całemu rodzajowi ludzkiemu. Przyrodnicy zaś oskarżani przez teologów o fałszowanie prawdy niejednokrotnie wykazywali, iż wypowiedzi zawarte $w$ Biblii są sprzeczne $z$ wynikami odkryć naukowych, a tym samym obraz stworzenia człowieka propagowany przez teologów jest fałszywy

20 Ha£aczen B., Antropogeneza w teologii katolickiej XX wieku, "Studia Theologica Varsoviensia"13(1975)2, 47-80. 
i niezgodny z wiedzą przyrodniczą. Tak to zarówno teolodzy, jak i przyrodnicy mieszali dziedziny swoich kompetencji - teolodzy wypowiadali się w kwestiach dotyczących biologii, zaś przyrodnicy czuli się kompetentni w interpretowaniu Księgi Rodzaju. Patrząc z perspektywy lat wydaje się, że teoria ewolucji sprowokowała zarówno przyrodników, jak i filozofów do podjęcia refleksji nad fenomenem człowieka. Dziś, choć oficjalne stanowisko Kościoła wyrażone choćby przez Jana Pawła II w 1996 roku kończy pewien etap nieporozumień, jednak wciąż nie można powiedzieć, że wszystkie problemy zostały ostatecznie rozwiązane ${ }^{21}$. Tym samym przeprowadzona ankieta dotyka jak najbardziej aktualnych problemów. Wstępna analiza ankiet pozwala sądzić, że dalsze prace wskażą kierunki w jakich powinny zmierzać kolejne badania. Być może ukażą one możliwość budowania komplementarności religii i nauki.

\title{
On Evolution and Creation - Preliminary analysis of the Student and Teacher Questionnaire
}

\author{
SUMMARY
}

The paper presents the results of the research which was carried out as part of the project: Current controversies about human origins. Between anthropology and the Bible. This project focuses on the supposed conflict between natural sciences and some branches of the humanities (notably philosophy and theology) with regard to the origin of man. The research was aimed at finding out whether such a conflict really exits. For one thing, we cannot exclude the possibility that these would-be controversies have no factual ground and that their significance is inflated by American popular literature. If, on the other hand, we assume that the conflict is real, it should be worthwhile examining its sources. Such an approach may prove helpful in systematising the highly emotional debates about the origin of man. One of the ways of tackling the issue was the questionnaire which was distributed among students, teachers and university professors. Our respondents represented three disciplines: theology, philosophy and the natural sciences. The paper will present selected results of the questionnaire which was addressed to a group of school teachers, whereas the responses of the students are given less attention in order to

${ }_{21}$ Fragment przemówienia Jana Pawła II do członków Papieskiej Akademii Nauk w 1996 roku: „Nauki doświadczalne z coraz większq dokładnościq badaja i opisuja wielorakie przejawy życia umieszczając je na skali czasowej. Moment przejscia do sfery duchowej nie jest przedmiotem obserwacji tego rodzaju. Może ona jednak ujawniać na płaszczyźnie doświadczalnej cały zespół bardzo ważnych oznak specyficzności istoty ludzkiej. Natomiast doświadczenie poznania metafizycznego(...) należy do sfery analizy i refleksji filozoficznej”. Magisterium Kościoła wobec ewolucji, „L'Osservatore Romano"1(1997)19. 
emphasise the teachers' point of view. The teachers of religion and the natural sciences (biology, chemistry and physics) and the students of theology, philosophy and the natural sciences (specialising in biology and environment protection) were asked to fill in the form consisting of eleven questions. These questions concerned the following issues: the existence of the conflict between evolutionism and creationism, the definitions of creation and evolution, the existence of the spiritual element in man, ways of interpreting the Bible (esp. the first chapters of the Book of Genesis). Out of 1000 questionnaires sent out, we received 449 , which should be considered a satisfactory number, given the fact that it was the first time this type of research was carried out in Poland.

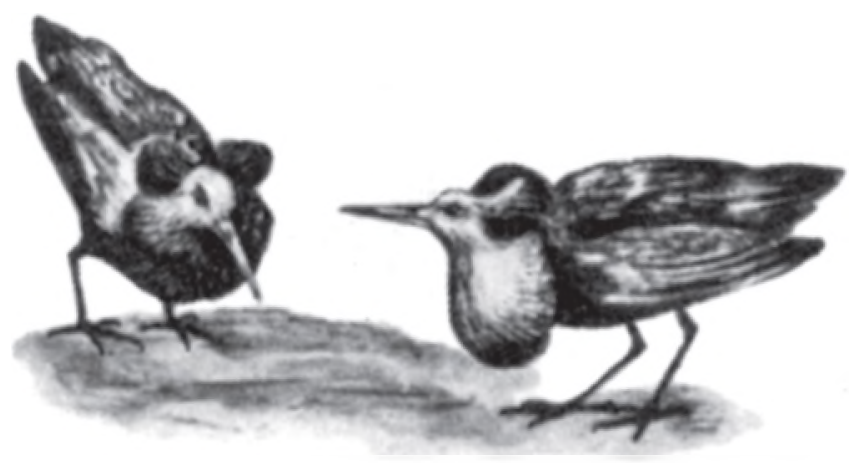

\section{Batalion}

